\title{
CAREER AND LIFE-BALANCE OF PROFESSIONAL WOMEN: A SOUTH AFRICAN STUDY
}

\author{
THANA WHITEHEAD \\ ME KOTZE \\ Programme: Leadership in Performance and Change \\ Faculty of Economic and Management Sciences \\ Rand Afrikaans University
}

\begin{abstract}
A woman's ability to balance multiple life-roles is directly related to her physical and mental well-being, and her career performance and success. This study aims to infer a theoretical framework for the in-depth understanding of the phenomenon of life-balance in the lives of 24 South African professional women. The Grounded Theory as a qualitative method was applied to derive a theory about the phenomenon inductively. Purposeful sampling was used to identify 24 professional women. In-depth interviews and a group session were conducted to gather data, and to confirm themes and concepts on which the theoretical framework was based. It was concluded that life-balance is a life-process with a cyclical nature, and a useful tool for achieving personal growth. Life-balance is therefore not "one, single ultimate experience", but a series of individual experiences unfolding over time, which could be better described as "life-balance moments".
\end{abstract}

\section{OPSOMMING}

'n Vrou se vermoë om meervoudige lewensrolle te balanseer is direk verwant aan haar fisiese en geesteswelsyn en ook haar loopbaanprestasie en -sukses. Hierdie studie het ten doel om ' $n$ teoretiese raamwerk af te lei uit die indiepte begrip van die lewens-balansverskynsel van 24 Suid-Afrikaanse professionele vroue. Die Begronde Teorie as ' $n$ kwalitatiewe metode is toegepas om ' $n$ teoretiese model induktief van die verskynsels af te lei. Doelgerigte steekproefneming is gebruik om 24 professionele vroue te identifiseer. In-diepte onderhoude en 'n groepsessie is gevoer om data in te samel en om die temas en konsepte waarop die teoretiese raamwerk gebaseer is, te bevestig. Daar is tot die slotsom gekom dat lewensbalans ' $n$ lewensproses is met ' $n$ sikliese aard en ' $n$ nuttige instrument om persoonlike groei te bewerkstellig. Lewensbalans is dus nie "een enkele beslissende erevaring" nie, maar ' $n$ reeks van individuele ervarings wat oor tyd ontvou en wat ten beste beskryf kan word as "lewensbalans momente".

Family and work are the two most important domains for many adults. When conflicts between these two domains occur, there are potentially adverse effects for individuals, families and organisations (Andrews \& Withey, 1976). Although men increasingly express interest in a more balanced commitment to their work role, it is women who experience the highest levels of conflict between work and family, since women are still expected to perform the bulk of family and household tasks and responsibilities (Burke, 2001). Since the Second World War women have played an increasingly important role in the economies of both developing and developed countries, and South Africa is no exception. Together with political and economic transformation, the transformation of the labour market, and the increased numbers of women occupying positions of leadership, the role of women in the socioeconomic environment is a significant development in the history of this country (Booysen, 2000; Verhoef, 1996).

Statistics concerning the economic power of women are staggering: the South African woman is becoming an economic force to be reckoned with (De Bruin, 2000). In $2000,40 \%$ of the economically active population of South Africa were women. Although more men $(60 \%)$ than women $(40 \%)$ were employed, there were more professional women (55\%) and administrators (69\%) than men (De Bruin, 2000). However, at management level in the private sector, women have not done so well. Although $28 \%$ of management posts were filled by women in 2000 (compared to 19\% in 1990), the ratio is inadequate when compared to men, and is a source of concern for both society and business. This trend, combined with the inequality in earning (whereby women generally earn $16 \%$ less than men), poses a big challenge for South Africa and countries all over the world (De Bruin, 2000). To be able to achieve sustainable political success and economic growth, the role of women is essential. According to Booysen (1999), there exists a need for feminine values in leadership and organisational change so that organisations can meet the

Requests for copies should be addressed to: T Whitehead, Department of Human Resource Management, RAU University, PO Box 524, Auckland Park, 2006 challenges of the next millennium more successfully. As a result, an increasing number of women are engaged in performing multiple roles at various times in their lives.

\section{Multiple roles and professional women}

One of the leading authors in Career Psychology, Donald Super, identified six common life-roles (Super, 1995). He also indicated that the need to balance these different roles simultaneously is a reality for most individuals at various stages throughout their lives. Rather than following a transitional sequence from one role to another, women are required to perform an accumulation of disparate roles simultaneously, each one with its unique pressures (Kopp and Ruzicka, 1993). Multiple role-playing has been found to have both positive and negative effects on the mental health and well-being of professional women (Anonymous study, 1990). In certain instances women with multiple roles reported better physical and psychological health than women with less role involvement. In other words, they cherished motivational stimulation, self esteem, a sense of control, physical stamina, and bursts of energy (Doress-Worters, 1994). However, multiple roles have also been found to cause a variety of adverse effects on women's mental and physical health, including loss of appetite, insomnia, overindulgence, and back pains (Hughes and Glinsky, 1994).

As society moves to a more equal distribution of work and family responsibilities between the sexes, conflict and confusion between these two roles have become a major concern for both organisations and individuals (Anonymous study, 1990). The phenomenon of work-family conflict is increasingly experienced by women (Fu and Shaffer, 2001). Work-family conflict is generally defined as a form of inter-role conflict in which compliance to one of the role pressures makes it more difficult to comply with the other (Fu and Shaffer, 2001).

Consequently, it seems as if professional women in the $21^{\text {st }}$ century have the exceptional challenge of balancing the multiple tasks associated with their homemaker and work roles, namely, fulfilling the responsibilities of mother, caregiver, 
spouse and employee simultaneously. It is also clear that women's ability to balance these roles has a direct bearing on their physical and mental well-being, as well as their career performance and success (Burke, 2001; Burke and Mc Keen, 1996; Facione, 1992; Sharma, 1999). It is suggested that it may be more difficult than ever to manage a balanced commitment to one's work and personal life (Burke, 2001). As a result of organisations being faced with heightened competition globally, employees experience increasing performance pressures. The hours spent in the workplace, especially for managers and professionals, are increasing. High performance organisations have raised their expectations regarding time, energy and work commitment. The dual role women have to play makes it difficult for them to meet these higher organisational expectations (Hochschild, 1997). They are thus faced with a unique challenge to balance the competing expectations of work and home, along with all their other roles.

During the past decade, an increasing number of articles and books have promoted the importance of life-balance (AaronCorbin, 1999). This indicates the current concern within society and organisations about the impact of multiple roles on the health and well-being of professional women, and its implications regarding work and family performance, and women's role in society.

In a review of international literature, the following variables influencing the experience of life-balance were identified:

a) the multiple roles performed by women (Adelman, 1994; Carlson, Kacmar and Williams, 1998; Facione, 1992; Super, 1995);

b) role strain experienced because of multiple roles, i.e. role conflict and role overload (Fu and Shafer, 2001; Greenhaus and Buetell, 1985; Kim and Ling, 2001);

c) organisation culture and work dynamics. Organisational values supporting work-life-balance have positive work and personal well-being consequences( Burke, 1997,2000,2001; Stover, 1994);

d) personal resources and social support. Several studies confirmed the positive relationship between personality, practical and emotional support and well-being (Amatea and Fong, 1991; Gill and Davidson, 2000; Sharma, 1999);

e) career orientation and career stage. Women careers need to be viewed in the context of their life course and time lines. (Rapaport and Rapaport, 1980; White, 1995); and

f) coping and coping strategies. Women use both emotional and problem-focused coping strategies to deal with role conflict (Folkman and Lazarus, 1984).

Research and literature within the South African context seems to be more limited. This is not surprising: the emergence of women in the developing socio-economic environment happened more slowly and later on than in developed countries such as the United States and Britain. Over the past three years research on the topics of women's careers, women in positions of leadership, multiple roles, coping strategies and mechanisms, and role conflict has been more prominent (Booysen, 1999,2000; Brink en de la Rey, 2001; Dimati, 1997; Jano, 2000; Redelinghuys, Botes and De Wet, 1999). This study is motivated by the lack of knowledge and understanding about professional women's subjective experience in balancing their lives within a South African context. The aim of this study is therefore to gain an in-depth understanding of the meaning of life-balance for South African professional women, and the factors, which influence and support the experience thereof.

\section{METHOD}

The study aimed to answer the following research questions:

1. What is an acceptable definition of the concept of lifebalance for professional women in South Africa?
2. What are the key supporting factors for professional women in successfully balancing their life-roles of work/career, family and self?

3. What are the key factors which influence the phenomenon of life-balance, and the achievement or non-achievement thereof?

\section{Research procedure}

The literature review revealed limited research on the concept of life-balance in South Africa. An attempt, therefore, to proceed directly to a positivistic approach to measure a concept that has not yet been fully explored will put ontological restrictions and limitations on the study of such a phenomenon. The study was therefore conducted within a qualitative paradigm, and the Grounded Theory method was used to develop an inductively derived theory (Strauss and Corbin, 1990). This method enabled the researcher to study the phenomenon of life-balance holistically within its context, and facilitated the systematic generation of a theory from, and grounded in, the data.

The qualitative data collection techniques in this study included interviews (in-depth, unstructured) and a focus group session. During the interviews open-ended questions were put to participants to obtain their specific experience of life from a grounded perspective. The focus group was conducted, as proposed by Schurink (2001), in an open conversation style, whereby participants were given an opportunity to make comments, ask questions of other participants, or respond to the comments of others. The focus group enabled the researcher to inductively confirm, and further develop, concepts and theories grounded in, or reflecting intimate knowledge of, the women participating in the group session. In order to ensure that all the data was accurately recorded, interviews were audiotaped, and extensive notes were taken during the interviews and the focus group.

\section{Participants}

The purposeful sampling method was used in combination with the chain reference sampling and theoretical sampling techniques identified by Patton (1990). Data was collected from twenty-four participants and analysed until the sample had been theoretically saturated, that is, no new data regarding the identified concepts emerged, and the relationship between the various concepts had been well established and validated (Strauss and Corbin, 1990). Of the 24 women in the sample, ten occupied executive or senior management positions in the private sector, five occupied executive or senior management positions in the public sector, five owned their own businesses or were self employed and practising their professions, and four worked in a management capacity at Non-Governmental Organisations (NGO's). The mean age of participants was thirty-six, with their ages ranging from thirty to forty two. The sample included eleven white women, five black women, and eight coloured women Of the sample, nine had one child, twelve had two children, and three had three children.

\section{Data Analysis}

Based on the suggestions of Strauss and Corbin (1990) and Creswell (1994), data analysis was conducted systematically whereby the researcher keeps track of emerging themes during the data gathering process, and develops concepts and propositions to make sense of the data. The processes of data collection and data analysis were interwoven from the beginning of the study. Analysis during data collection provided Whitehead with the opportunity to move back and forth between thinking about the existing data and generating strategies for collecting new data. Whitehead kept track of emerging themes, read through field notes, and developed concepts and propositions to begin to make sense of the data. Coding was used systematically to develop and refine data 
interpretation. The coding process involved bringing together and analysing all the data with a bearing on the themes, ideas, concepts, interpretations and propositions.

\section{RESULTS}

The main findings indicated that professional women experienced similar pressures and challenges, irrespective of cultural background, in their efforts to balance their multiple roles. Of the 24 women interviewed in the study, fifteen indicated that they did experience life-balance, and nine indicated they did not. As suggested by Strauss and Corbin (1990) and Cresswell (1994), several themes relating to the phenomenon of life-balance emerged from the data analysis. In the next section these themes will be discussed. From the themes it was possible to develop responses to the formulated research questions and to link international and South African studies with the results of this study.

\section{A definition of life-balance for professional women}

According to the participants' responses, the experience of lifebalance seems to be elusive and ever changing for professional women. Different experiences of life-balance are evident, and it is clear that what represents life-balance to one person is not necessarily applicable to another.

The first results which can be drawn from the study in defining the phenomenon of life-balance include:

- It is important to consider all the roles performed by an individual over her lifetime;

- What constitutes life-balance for one person, might not be applicable to another;

- Self-awareness is the main point of departure from which any individual achieves life-balance;

- It is important to accept "who you are" and what is important to you in order to experience life-balance;

- It is also important to take responsibility for the choices you make;

- Life-balance has a cyclical nature, and therefore it is important to be constantly aware of your life experiences;

- Life-balance is not an "end", but a process, and an everpresent tool for achieving personal growth;

- Life-balance is therefore not "one, single ultimate experience", but a series of individual experiences over time, which can better be described as "life-balance moments".

Participants reporting the experience of imbalance indicated that the areas most neglected by them referred to their relationship with their husbands or partners, the time devoted to themselves or leisure activities, and their involvement in their communities. The experience of life-balance seemed to be closely linked to whether a participant spent time on the roles, which were important to her. Several participants indicated that they were not experiencing life-balance because they were not prioritising either their life-roles or their time in accordance with what was important to them. A final observation was the close relationship between the participant's experience of life-balance and their experience of health and well-being. Participants who indicated a lack of lifebalance also experienced health and well-being issues. This included less serious conditions, such as insomnia, fatigue, regular 'flu and colds, as well as more serious conditions, such as panic attacks, depression and cancer.

\section{Roles performed by professional women}

Participants identified seven roles expected of them, including worker, mother, wife, housekeeper, family member (sister, child), community member, and friend. These identified roles coincide with the six life-roles defined by Super (1995). The findings from the interviews and focus group indicated that all participants were aware of the above roles, but viewed the importance of various roles differently, and therefore spent different amounts of time on them. The importance of a role and the time spent on it were closely linked to the life-priorities and life-stage of a participant. This finding supports the research conducted by Cook (1994), indicating that the amount of time and energy spent on a role determine that role's salience, that is, its significance. The ages of the participants, their children, and their parents were identified as examples of the variables, which determine the salience of a particular role in the participant's lifespan. This coincides with the career models of both Levinson (1987) and White (1995). They indicated that a woman's career had a direct relationship with her age. Participants also indicated they could identify, and felt more comfortable, with some roles but not others. This finding supports the research of Carlson, Kacmar and Stephina (1995): life-roles provide sources of identity, and different people gain their identity from different roles. Situational conditions also appear to influence the time spent on a role, and thus its salience. Poole and Langan-Fox (1997), in their studies on professional women, found that it was important to view the roles performed by women within the context of their "life course", indicating that at different stages of a woman's life, different situational factors are influential, which in turn influence the salience of a specific role. All participants indicated that the beliefs and attitudes of society significantly influenced how they perceived the importance of their multiple roles. Furthermore, participants indicated that conflicting views still exist within the society regarding the career and family roles of women. It was also clear that some participants seemed to gain energy from performing multiple roles, whereas others viewed it as overwhelming and stressful. This finding supports the studies of Doress-Worters (1994) and Hughes and Glinsky (1994), indicating inconsistent trends in the effect of multiple roles on the health and wellbeing of women. The main finding was that twenty of the twenty-four participants were responsible for the children and household tasks. This supports the findings of Berardo, Shehan and Leslie (1987) and Grant, Simpson and Rong (1990), suggesting that evidence exists that women still carry the primary responsibility for family and household activities. Only in four instances were the husbands playing an active and true partnership role, taking a shared responsibility for children and household tasks. Husbands, in most instances, didn't seem to be negative about getting involved, but it would generally happen from a "helping" perspective, and not as a natural response to a situation.

The experience of conflict between the multiple roles performed by professional women

All participants indicated that the experience of role conflict was dynamic, a constant challenge, and experienced in varying degrees over time. Only six participants indicated that they constantly experienced feelings of conflict. These participants were the ones with the youngest children, and/or with only one child; thus lending support to Bedeian, Burke and Moffet (1988) and Buetell and Greenhaus' (1980), who found that more role conflict is experienced by women with younger children. According to Sharma (1999), the support and involvement of a husband positively relates to lower levels of role conflict experienced by working women. Participants all indicated their husbands' support of their careers, although only a minority experienced their husbands' proactive support and involvement with the children and housekeeping. The four participants who indicated their husbands to be a true partner in all instances, also reported low levels of role conflict. This finding thus supports Sharma's perspective. Throughout the data analysis process it was clear that the one constant dynamic influencing the experience of role conflict amongst participants was when a disproportionate amount of time was spent on a role as compared to the identity gained from that 
role. For example, participants for whom career and work were a large part of "who they are" but were not spending enough time on this role due to family or other role obligations, experienced high levels of role conflict. This supports the findings of Carlson et al. (1995): conflict arises when an individual who values a particular role is forced by situational constraints to spend less time than she would like on that role. In a study conducted by Carlson et al. (1998), participants indicated that they experienced work demands to negatively influence family responsibilities in more instances than family demands influence work responsibilities. All participants indicated that the type of conflict most often experienced is that of job-parent conflict.

\section{The meaning of career and work in the lives of professional women}

All the participants in the study described themselves as "career-orientated". With the exception of one participant, all participants indicated that they did not consider their careers as "just doing a job". Their career was part of " who they are". This finding supports Raynor (in Poole and Langan - Fox, 1997), who defined career as the shaping and developing of self-identity. All participants indicated that their main motivations for working were related to intrinsic work values that give people's lives meaning. Consequently, this supports the research conducted by Woodd (2000), who found that women rated the intrinsic value of their jobs higher than their male counterparts. However, although remuneration was not cited as a main reason, participants did indicate that they also worked to be financially independent from their husbands, to provide for a better future for their children, and to maintain a certain standard of living.

Another important finding indicates that the majority of participants had already moved through their first careers, and were currently involved in second or later careers in other related or, in some instances, unrelated fields.

\section{Personal characteristics and life}

Participants seemed to share the opinion that certain personal characteristics were more conducive to the achievement of lifebalance than others. The data analysis indicates an overwhelming agreement that the distinguishing personal characteristic needed to achieve life-balance is to "know and understand yourself". Furthermore, it was important to prioritise life-roles in alignment with "who you are", to make choices about time and areas of focus, and to take control and responsibility for choices made. To have confidence in yourself and your abilities, and a positive approach to dealing with the "curveballs life throws at you" also seemed to be important in the achievement of life-balance.

\section{The presence and extent of support structures}

The main findings of the study on support structures identified, firstly, the need for support from the husband in the woman's career, and secondly, the need for a stable and strong immediate support structure. This is supportive of Kim and Ling (2001), who found in their studies of women entrepreneurs that the spouse's attitude and emotional support have the greatest influence on reducing women's conflict and stress levels. Only two participants indicated that their husbands were completely involved in the upbringing of their children and that there was no difference in the level of responsibility between husband and wife. All participants had some degree of household support. Twenty of the twenty-four participants had full-time housekeeping support, living in or working five days a week. The other four had support for a minimum of two days a week. In the case of fourteen participants, the grandparents were actively involved in the taking care and upbringing of children. Eight of the participants had their children attending a crèche or aftercare facility, three made use of an Au Pair (either full-time or in the afternoons), and the rest either had a full-time housekeeper or a parent involved, or, in the case of flexible working hours, took responsibility themselves.

The organisation and life-balance

A significant finding was that all participants in full-time positions in the private, public or NGO sectors indicated a complete lack of support and understanding for working women from their organisations. These experiences of professional South African women support the findings of Burke and McKeen (1996), who found in their studies of professional women in the USA a complete lack of organisational savvy in dealing with professional women, and a working environment not at all conducive to living a balanced life. Burke (2001) further found that organisations are merely paying lip service to the work/life-balance issue. Flexible working hours seemed present in a minority of organisations, and the participants in this study indicated that they were expected to keep normal, fixed working hours. In many instances employers considered expectations of working after-hours to be normal. Morrison, White and Van Velsor (1997) found that after-hour meetings and overtime made it more difficult for women to balance their roles. However, Hyman, Baldry, Scolarios and Bunzel (2002) indicated in their research that the issue of work/ life-balance is more complex than just making simple adjustments to working time. They suggested that in order to address the issue of work/life-balance successfully, organisations need to review their current value and belief systems and promote a culture of work/life-balance. Another important experience related by the participants is the presence of a "male base of performance" within their organisations. The participants experienced constant comparisons to their male colleagues, resulting in their "working harder and longer hours" than their male counterparts. The above findings coincide with the views of Burke $(2000,2001)$, Burke and McKeen (1996), Davidson, Cooper and Baldini (1995) and Mavin (2001), which indicate that male career models, prejudices, and sexual stereotypes are still prevalent in organisations.

\section{The experience of coping and the overall well-being of professional women}

The experience or non-experience of life-balance was strongly associated with experiences of coping and well-being. This supports the studies conducted by Burke (2001) and Sharma (1999), which found a positive relationship between the experience of life-balance and the health and well-being of professional women. Participants used a combination of coping strategies. They indicated the need for planning and proactive problem-solving, including the proactive identification of support-related needs and the implementation of the necessary support structures, as well as the upfront structuring and planning of a week. These coping strategies, as listed by Brink and De la Rey (2000) above, were also reported by participants in this study. The respondents included changing the situation, minimising the significance of a situation, rationalising, obtaining social support, accepting responsibility, planning, and positive reappraisal in their responses. The finding of Dimati (1997) that women tend to seek social support to cope was confirmed by participants. All the participants indicated the need for greater social support in the form of interaction with other women facing similar challenges. To counter the effects of an imbalance in their lives, participants all stressed the importance of nutrition and exercise. However, they all indicated that they were not currently spending enough time on this. Their reasons included, "I do not have the time", "If I have to choose between spending time with my children or going to the gym, I rather spend any available time with them", and "I feel guilty when I take time out for myself, having already spent so much time away from my children". 


\section{DISCUSSION}

As stated, the main purpose of this study is to explore the lifeworlds of professional women in South Africa in order to arrive at a theoretical framework of the phenomenon of life-balance. In the next section the original research questions will be discussed, after which a proposed theoretical framework for lifebalance will be suggested.

\section{What is an acceptable definition of life-balance for} professional women?

According to the participants' responses, the experience of lifebalance is an elusive and ever changing one for professional women. Different experiences of life-balance exist, and it is clear what represents life-balance to one person is not necessarily applicable to another. This raises the question of whether it is possible to have an all-encompassing definition of life-balance, applicable to various people in various situations. The first conclusions to be drawn from the study on a definition of lifebalance include:

- It is important to consider all the roles performed over a lifetime;

- What constitutes life-balance for one might not apply to another;

- Self-awareness is the main point of departure from which to achieve life-balance;

- It is important to accept "who you are" and what is important to you;

- It is also important to take responsibility for the choices you make;

- Life-balance has a cyclical nature, and therefore it is important to be constantly aware of your life experiences;

- Life-balance is a process and a tool for achieving personal growth;

- Life-balance is therefore not "one, single ultimate experience", but a series of individual experiences over time, which can be called "life-balance moments".

Another conclusion is that two main types of factors influence and support the experience of life-balance: internal/influential factors, and external/supporting factors. The study indicates that the key differentiator between women who experience life-balance and those who do not is the existence of internal/influential factors. Without these factors, life-balance will never be truly experienced, even though external/ supporting factors might exist.

What are the key factors which influence the phenomenon of life-balance and the achievement or non-achievement thereof?

The key factors influencing the experience of life-balance include:

- the level of self-awareness at which a person lives life;

- the ability to "know and understand yourself";

- the ability to take responsibility for your decisions and life choices;

- the ability to understand and deal with personal fears;

- the application of proactive coping strategies;

- a positive attitude towards life and dealing with chosen demands; and

- a level of trust in others who assist and support you.

When a woman establishes these internal factors, choices regarding career performance and other roles are made, enabling the experience of life-balance.

What are the key supporting factors for professional women in successfully balancing their life-roles?

One conclusion drawn from this study is that the main differentiating supporting factor for professional women is the support and involvement of their husbands with regards to both their careers and the family and homemaking.
The study further concludes that the following external variables are supportive:

- Societal views and attitudes: The views and attitudes of society regarding the role of women are important in this discussion. In most instances participants indicated having experienced conflicting views of society.

- Support structures: The existence and extent of support structures are instrumental in the experience of life-balance. Examples of support structures include housekeepers, au pairs, home managers, friends and/or parents and family, and after-care centres or crèches.

- Organisational values and support: The study confirmed that the non-existence and non-awareness of a "balanced lifestyle organisational culture" and organisational support impacted negatively on participants' experience of lifebalance. A conclusion can be drawn that an organisation culture which supports balanced life-styles and provides support and flexibility through human resource policies and practices will better enable female employees to experience life-balance.

In order to understand and confirm this study's above conclusions, two Life-balance Models were developed. The first model guides the discussion on a definition of life-balance and the characteristics associated with the phenomenon. In Figure 1 (Defining Life-balance: A Holistic Approach) an outline of this model is provided. This model represents a holistic view of the phenomenon of life-balance. From the conclusions reached regarding a definition, it seems as if there are two prerequisites for the experience of true life-balance, namely selfawareness and a high level of consciousness at which a person lives her life. These two dynamics are presented as two axes on the proposed model. The horizontal axis represents the level of self -awareness and refers to the level of awareness an individual has of her own identity, and what is important in life to her. The vertical axis represents consciousness and refers to the level of consciousness at which an individual lives her life. In a woman's lifetime she can "pass" through the four stages of this model a few times. Each stage within the model is characterised by levels of self-awareness and consciousness, resulting in experiences of life-balance, growth and self-development.

The second model was developed to present an understanding of the external/supporting and internal/influencing factors present in the experience of life-balance. In Figure 2 (A Lifebalance Process Model) an outline of the model is presented. The experience of life-balance is supported and influenced by both internal and external factors. An external dynamic, namely family background, or the "way we have been brought up", impacts and shapes the identity of an individual. On the other hand, internal factors and abilities, such as selfawareness and reflection, are important in the understanding of one's own needs and preferences, and the shaping of identity. When an individual knows and understands herself and her preferences, she can make choices based on this understanding. As indicated in the results of this study, the one distinguishing personal characteristic which facilitates the experience of life-balance is "to know and understand yourself' and to prioritise life-roles accordingly. Choices once again are either supported or not supported by external factors. Society plays an important role in the choices women make, as societal views and attitudes seem to be an important support base for the choices women make. In this study participants indicated experiencing conflicting expectations from society. However, being true to one's identity, and making choices in alignment with "who you are", is an important building block in the experience of life-balance. The choices a woman makes include the roles she wants to perform in her lifetime. To perform these roles in a balanced manner successfully, external support factors need to be considered, namely, husband support, work arrangements, support structures and an organisational culture. Internal factors which influence the performance of multiple roles 


\section{Sub-Conscious}

STAGE 1

1. Low level of self-awareness

2. No clear picture of "who am I?".

3. Living life on a sub-conscious level.

4.Living life as dictated by others and the external environment.
STAGE 4

1. Experience life-balance sub-consciously.

2. Living life in alignment with

"who you are" sub-consciously.

3. Taking time to reflect.

4. Decision to further grow.
Low Self-Awareness

STAGE 2

1. Unfulfilled, questioning roles and identity.

2. Awareness of need for balance.

3. Living life on a conscious level not comfortable
High level of Self-Awareness

STAGE 3

\section{Figure 1: Defining life-balance: A holistic approach}

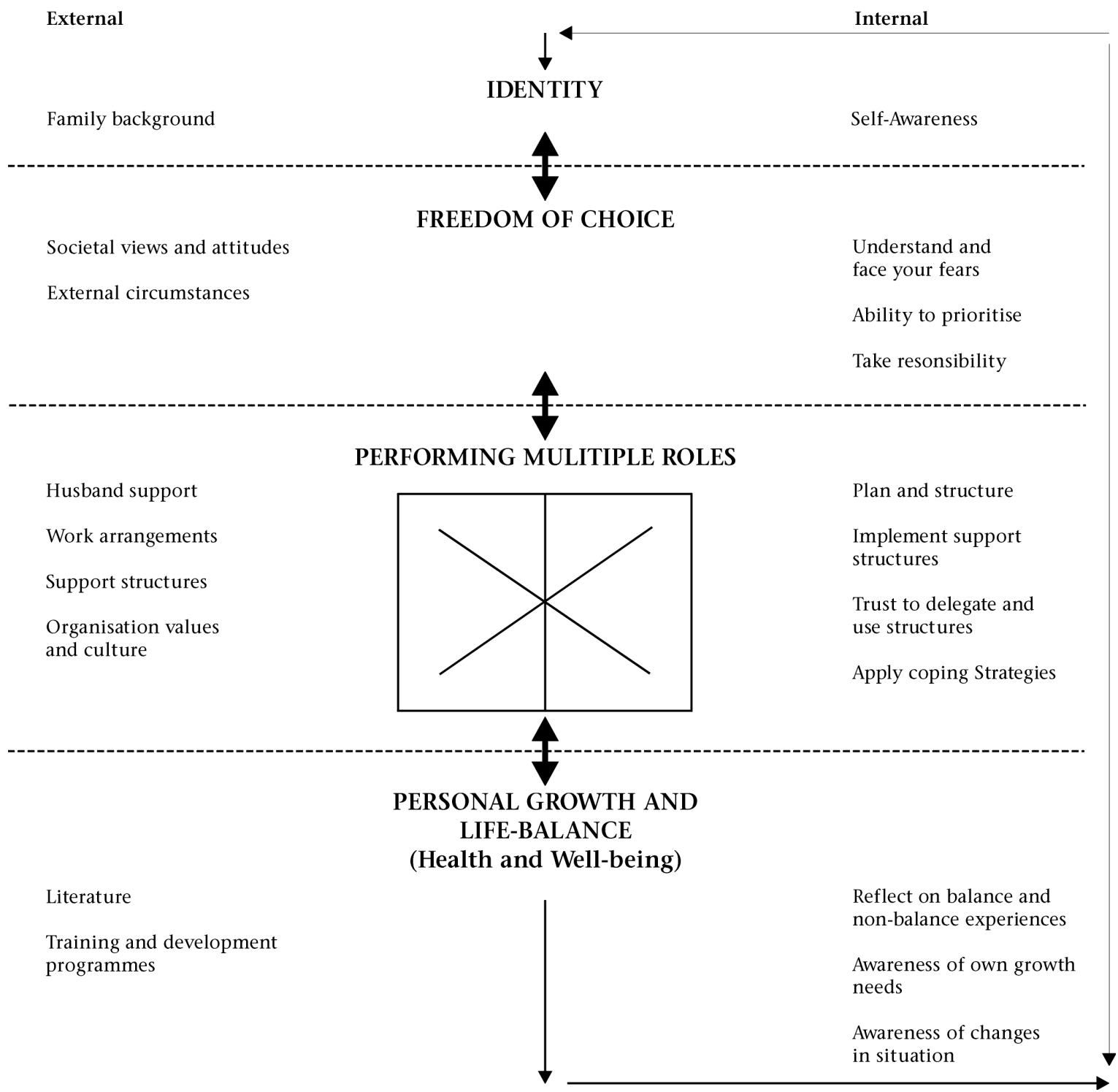


include the ability to plan and structure proactively, the implementation of support structures, trust in others, and the ability to apply appropriate coping strategies. The results of this study indicate that personality and personal resources have a positive relationship with the experience of lifebalance. In performing multiple roles an individual will grow and develop, and, if conducted in alignment with her identity, an individual can experience life-balance, health and wellbeing in the process. Examples of external factors which support the experience of growth and development include literature, and training and development courses. Internal factors which play a role in self-development and growth are the ability to reflect, and the level of self-awareness. This, in turn, shapes identity.

It is important to consider that in order to experience lifebalance both external/supporting factors and internal/ influencing factors are important. It has, however, been concluded in the discussion of this study's research questions that should the internal factors not be present in an individual's life, true life-balance will not be experienced, even if the external factors are present.

\section{Limitations and recommendations}

As with all research, this study has limitations. First and foremost, it must be noted that because of the qualitative nature of the study, one cannot generalise the present study's results to working women as a whole. Participants represented working women in the Western Cape, were not (in terms of quantitative research) representative of a national sample of working women. Once again, this could impose certain limitations on the generalisation of the findings. As this field of research is still relatively new within the South African context, there are a number of research topics, which could be investigated. In the first place, a research opportunity exists to develop and test the reliability and validity of the "Life-balance Questionnaire" which was developed as a secondary objective of this study. Since this study focused on professional women, there is an opportunity to conduct a similar study amongst other women in the workplace, and also to investigate the phenomenon of life-balance among single mothers. This study can also be further researched by including the husbands of the participants in the study. Other interesting and related future research topics can include: to establish the relationship between various personality types and life-balance experiences; to investigate the extent of life-balance friendly organisation cultures in South Africa; and to conduct a study on males and their experiences of life-balance.

\section{REFERENCES}

Aaron-Corbin, C. (1999). The multiple-role balancing act. Management Review, 88 (9), 62-65.

Adelmann, P.K. (1994). Multiple roles and health among older adults. Research on Aging, 16 (2), 142-166.

Amatea, E. S. \& Fong, M. L. (1991). The impact of role stressors and personal resources on the stress experience of professional women. Psychology of Women Quarterly, 15, 419430.

Andrews, F. \& Withey, S. (1976). Social indicators of wellbeing. New York: Plenum Press.

Anonymous Study (1990). Women with multiple roles: Role compatibility perceptions, satisfaction, and mental health. Journal of Marriage and Family, 52 (1), 63-74.

Buetell, N.J. \& Greenhaus, J.H. (1980). Some sources and consequences of inter-role conflict among married women. Paper presented at the annual meeting of the Academy of Management: Vol. 17, (pp.2-6). California.

Bedeian, A.G., Burke, B.G. \& Moffet, R.G. (1988). Outcomes of work-family conflict among married male and female professionals. Journal of Management, 14 (3), 475-491.
Berardo, P.H., Shehan, C.L. \& Leslie, G.R. (1987). A residue of tradition: jobs, careers, and spouses' time in housework. Journal of Marriage and Family, 49, 381-390.

Booysen, A.E. (1999). Challenges facing black and white women managers in South Africa. Management Today, 16 (5), 22-28.

Booysen, A.E. (2000). Towards a more feminine business leadership for the 21st century: a literature overview and a study of the potential implications for South Africa. South African Journal of Labour Relations, 1 (23), 31-54.

Brink, B. \& De la Rey, C. (2001). Work-family interaction strain: coping strategies used by successful women in the public, corporate and self-employed sectors of the economy. South African Journal of Psychology, 31 (4), 55 - 61.

Burke, R.J. (1997). Culture's consequences: organisational values, family-friendliness and a level playing field. Women in Management Review, 12 (6), 222-227.

Burke, R.J. (2000). Workaholism among women managers: personal and workplace correlates. Journal of Managerial Psychology, 15 (6), 520-534.

Burke, R.J. (2001). Organisational values, work experiences and satisfactions among managerial and professional women. The Journal of Management Development, 20 (4), 346-354.

Burke, R. J. \& McKeen, C.A. (1996). Employment gaps and work and career satisfaction of managerial and professional women. International Journal of Manpower, 17 (1), 47-55.

Carlson, D.S., Kacmar, K.M. \& Stepina, L.P. (1995). An examination of two aspects of work-family conflict: time and identity. Women in Management Review, 10 (2), 17-25.

Carlson, D.S., Kacmar, K.M. \& Williams, L.J. (1998). The development and validation of a multi-dimensional measure of work-family conflict. Paper presented at the 1998 Academic Management Meeting. California.

Cook, E.P. (1994). Role salience and multiple roles: A gender perspective. The Career Development Quarterly, 43, 85-94.

Creswell, J.W. (1994). Research design: qualitative \& quantitative approaches. California: Sage Publications.

Davidson, M.J., Cooper, C.L. \& Baldini, V. (1995). Occupational stress in female and male graduate managers - a comparative study. Stress Medicine, 11, 157-175.

De Bruin, W. (2000). Women: A growing economic force: An F and T Finance Week Feature. Finance Week, 22 September 2000, 37-47.

Dimati, I.N. (1997). Gender role attitudes, sense of coherence and coping among working women. Unpublished master thesis in clinical psychology, University of Medunsa, South Africa.

Doress-Wortes, P.B. (1994). Adding elder care to women's multiple roles: A critical review of the caregiver stress and multiple roles literatures, Sex Roles, 31, 597 - 613.

Facione, N. C. (1992). Role overload and health: The married in the waged labour force. Health Care for Women International, $15,157-167$

Folkman, S. \& Lazarus, R.S. (1984). Stress, appraisal, and coping. New York: Springer Publishing.

Fu, C.K. \& Shaffer, M. A. (2001). The tug of work and family. Personnel Review, 30 (5), 502-522.

Gill, S. \& Davidson, M.J. (2000). Problems and pressures facing lone mothers in management and professional occupations - a pilot study. Women in Management Review, 17 (8), 383-399.

Grant, L., Simpson, L.A. \& Rong, W.L. (1990). Gender, parenthood and work hours of physicians. Journal of Marriage and Family, 52, 39-49.

Greenhaus, J.H. \& Buetell, N.J. (1985). Sources of conflict between work and family roles. Academy of Management Review, 10 (1), 76-88.

Hochschild, A.R. (1997). The time bind. New York: Metropolitan Books.

Hughes, D.L. \& Glinsky, E. (1994). Gender, job and family conditions, and psychological symptoms. Psychology of Women Quarterly, 18, 251 - 270. 
Hyman, J., Baldry, C., Scolarios, D. \& Bunzel, D. (2002). Work-lifebalance for the knowledge worker? Paper presented at the $8^{\text {th }} \mathrm{Bi}$ Annual Conference of the International Society for the Study of Work and Organisational values (pp. 184-190). Poland, Academy of Humanities and Economics: Lodzi Academia Printers.

Jano, R. (2000). Role and career salience of dual career professional women. Unpublished masters thesis in psychology, University of the Western Cape, Cape Town.

Kim, J.L.S. \& Ling, C.S. (2001). Work-family conflict of women entrepreneurs in Singapore. Women in Management Review, 16 (2), 204-221.

Kopp, R. G. \& Ruzicka, F. M. (1993). Women's multiple roles and psychological well-being. Psychological Reports, p. $1351-1354$.

Levinson, D.J. (1978). The season's of a man's life. New York: A.A. Kopf.

Mavin, S. (2001). Women's career in theory and practice: time for change? Women in Management Review, 16 (4), 183-192.

Morrison, A., White, R. \& Van Velsor, E. (1987). Breaking the glass ceiling. Reading, MA: Addison-Wesley.

Patton, M.Q.(1990). Qualitative evaluation research methods. Newbury Park: Sage.

Poole, M.E. \& Langan-Fox, J. 1996. Australian women and careers. Cambridge: Cambridge University Press.

Rapoport, R \& Rapoport, R.N. (1980). Work, family and the career. New York: Praeger Publishing.

Redelinghuys, N., Botes, L.J.S. \& de Wet, M. (1999). Role conflict among women employees: fact or fiction. Society in transition, 30 (1), 54-68.
Sharma, S. (1999). Multiple roles and women's health: A multi-linear model. Equal Opportunities International, 18 (8), $16-23$.

Schurink, W.J. 2001. Qualitative Research. Paper presented at the "Leadership in Performance and Change Doctoral Programme". Rand Afrikaans University.

Stover, D.L. (1994). The horizontal distribution of female managers within organisation. Work and Occupation, 21 (4), 385-402.

Strauss, A.L. \& Corbin, J. (1990). Basics of qualitative research: grounded theory procedures and techniques. Newbury Park: Sage.

Strauss, A. \& Corbin, J. (1994). Grounded Theory methodology: An overview. In Denzin, N., Lincoln, Y. Handbook of Qualitative Research. California: Sage Publications.

Super, D.E. (1980). A life-span, life-space approach to career development. Journal of Vocational Behaviour, 16, 282-289.

Super, D.E. \& Sverko, B. (1995). Life-roles, values, and careers: International findings of the work importance study. San Fransico: Jossey Bass Publishers.

Verhoef, G. (1996). The role of women in the South African economy. The South African Journal of Economics, 64 (3), 216 234.

White, B. (1995). The career development of successful women. Women in Management Review, 10 (3), 4-15.

Woodd, M. (2000). The move towards a different career pattern: are women better prepared than men for a modern career? Career Development International, 5 (2), 99-105. 